\title{
BICYCLE USAGE IN THE URBAN TRANSPORTATION: PRISTINA EXAMPLE
}

\author{
Dr. Sc. Beni KIZOLLI*, Prof. Asoc. Seda HATIPOGLU** \\ *UBT College, benikizolli@hotmail.com \\ **Gazi University, sedab@gazi.edu.tr
}

\begin{tabular}{|c|c|}
\hline Article history: & A b s t r a c t \\
\hline $\begin{array}{l}\text { Accepted O3 April } 2019 \\
\text { Available online } 30 \text { April } 2019\end{array}$ & $\begin{array}{l}\text { The aim of the research is to provide suggestions for increasing the use of bicycles, which are part } \\
\text { of the modern transportation policies. The methodology in the research was developed according to }\end{array}$ \\
\hline Keywords: & the physical characteristics of the city center in Pristina and the new regulations of the Pristina \\
\hline $\begin{array}{l}\text { Urban traffic, } \\
\text { Transportation Demand Management, } \\
\text { Bike Lane, }\end{array}$ & $\begin{array}{l}\text { Development Plan. In this context, in the questionnaires, the approach, demand and application } \\
\text { possibilities of the passengers against the other transportation systems (except private vehicles) were }\end{array}$ \\
\hline Pristina & $\begin{array}{l}\text { evaluated. The field research questions were asked to get the thoughts of public transport passengers } \\
\text { about these issues. The responses of } 782 \text { passengers that are directly or indirectly related with bicycle } \\
\text { usage. }\end{array}$ \\
\hline
\end{tabular}

As a result of these recommendations, Pristina will have two-way bicycle lanes with a length of 16 $\mathrm{km}$ to complete the cycling network. In this context, it was emphasized that the suggestions for the urban bicycle network in Pristina were evaluated in order of priority.

\begin{abstract}
Recommendations are given in accordance with the infrastructure of the route and it is expected that a regular transportation type will be provided to the urban transportation of Pristina by carrying out the arrangements on a $16 \mathrm{~m}$ wide road between the two sidewalks (platforms). In the new regulations, a two-way $4 \mathrm{~km}$ bike lane is proposed in the central ring of Pristina, as a result of the bicycle lanes that will form the bicycle network in Pristina to implement the bicycle public transport integration strategy in the future. Approximately $8.5 \mathrm{~km}$ two-way bicycle lane in central ring, $1.5 \mathrm{~km}$ two-way bicycle lane in the southwestern region and $2 \mathrm{~km}$ bicycle lane in the southeastern region has been proposed for Pristina.
\end{abstract}

\section{Introduction}

In urban areas, urban settlements are mostly preferred due to the population increase in developing capitals, while urban transportation has a key role due to the diversity of functions in the city center. Within the scope of daily necessities, urban transportation affects daily life and social order both materially and socially.

Within the borders of Pristina municipality, transportation between the urban and rural areas is carried out by means of private vehicles and public transportation and in this context, private vehicles are preferred primarily. Some sanctions of the government of Kosovo have been effective in this regard, for example, due to the ease of importing second-hand vehicles from Europe and the budget provided by the state border taxes of vehicle fuel imports, the increase in the use of special vehicles for political will does not cause a problem.

Within the framework of this situation, when the demands are answered, the supply is created simultaneously. For example, in 2002-2007, 163 road construction projects were realized and 12.6 million euros were invested. A different proof of this understanding is the investment of 22 million euros in 2010-2011 for road projects in Pristina.And as a result, theusage of 
privatevehicles are continuouslyincreasing. 300 thousand vehicles are being used in Kosovo.As a result of the sanctions imposed by the current management approach, it is seen that different approaches are needed to produce new solutions. Despite the fact that the urban traffic problems in the developed and developing countries of the world are solved within the framework of new understanding, problems such as road network issues and lack of parking in the city of Pristina can only be solved by increasing the roads, interchanges and parking areas.

Furthermore, the temporary relief provided by the new roads and intersections in line with this planning leads to additional demands. Therefore, in the framework of a strategic planning, the most efficient use of the existing road network should be ensured. The idea behind the TDM approach is to increase the diversity and efficiency of the transportation system. Transportation Demand Management (TDM) is a general term used to increase the efficiency strategies of transportation systems by considering motor vehicles. If the TDM method is implemented efficiently, it will have effective benefits over traditional transport management systems.

In this study, the application possibilities and benefits of cycling strategies will be examined by means of the Transportation Demand Management strategies which are considered as new approaches to solve urban traffic problems.

Within this framework, bicycle usage improvements that can be used according to traffic infrastructure among the TDM strategies in the city of Pristina have been evaluated.In the context of bicycle usage improvements, bicycle lanes are recommended in areas suitable for urban cycling in Pristina. A two-way bicycle lane along the route has been proposed in the new regulation throughout Pristina city center ring. In addition, bicycle lanes have been also proposed for the southwest and southeast of Pristina.During these applications, it is expected that a regular type of transportation will be provided for urban transportation in Pristina. In the process of bicycle usage improvements, traffic density will be reduced especially in neighborhoods and so the need for private parking in the urban center will also be reduced. The reason why the city of Pristina was chosen as the study area is because as the capital of Kosovo since the expansion of the settlements in the recent years, the majority of the young population and the use of private vehicles has an impact on air pollution and so there has been a need for a different transportation in terms of economy and health.

The favorable conditions provided by topography and climate can play an important role in the widespread usage of bicycles. In the study, the urban transportation plan is presented with examples of the decisions to be taken regarding the bicycle transportation. The aim of the research is to provide suggestions for increasing the use of bicycles, which are part of the modern transportation policies.

When examined carefully, although significant technical developments are seen in the brief history, the traditional approaches to the solution of the transportation problem appear to be the product of a medium policy: Developing the transportation infrastructure to meet the demand for passenger traffic. The problem in the whole approach is the obstruction of traffic, which is one of the surface aspects of transportation.In these approaches, the aim is to increase the accessibility of vehicles on blocked roadsand not the people (Elker, 1999).

Critical aspects of the traditional approaches to transportation can be grouped into three main groups: distorted efficiency understanding, lack of social content and indifference to environmental problems (Kılınçaslan, Elker andSutuciffe, 2012: 255).

Initially, these approaches to transportation supply generally improve traffic conditions; however, this leads to more widespread use of vehicles, resulting in new blockages. The new ways to overcome these new blockages and the temporary relief provided by the intersections create new additional demands and this creates additional capacity needs for urban area (Kılınçaslan, Elker andSutuciffe, 2012: 254).

The traditional approach which is known as "increasing the supply by increasing the demand ", not that it doesn't solve the problems but on the contrary, it has been entered into a growing vicious circle, and therefore, it has been searched for a new approach (Çelik, 1999).

The main objective of TDM is to reduce the number of vehicles using the road network and to provide a wide range of mobility opportunities for those who wish to travel.The term TDM includes both alternatives to the use of automobile alone and a support strategy that makes it attractive to use (Yüksel, 1998: 27)

In the study, the complementary aspects of different types of transportation are explained by mentioning the place of bicycle transportation among other alternative transportation types.By increasing bicycle use, it is aimed to reduce infrastructure costs (Condon and Isaac, 2003) and to create healthy communities in habitable environments (Brigham, 2002; Corsi, 2002; Kaplan and Ulvi, 2005). In the case of short or medium-distance journeys, the use of bicycles in the city is encouraged and increased in order to reduce the vehicles and to offer an alternative.

The use of bicycles comes into prominence in other transport systems, as a system that is necessary for the integrity of the society and enhances the social convergence between the people and human relations in general. The positive effects of bicycle use on human's physical (physical and physiological) and mental 
(psychological) health has favorable impact in social relationships of daily life (İyinam andİyinam, 1999). As with automobile journeys, the cyclist can travel at any time without waiting for a timetable (without waiting for the departure or transit time of the vehicle, such as the bus, tram and service vehicles).The user can determine the route himself / herself, go to the point that wants to reach in his / her own way and make a direct journey as in the car. This flexible and non-waiting structure in the route and schedule of bicycle trips ensures that bike trips are fast, without delay and reliable (Mert andÖcalır, 2010).

Climate and weather conditions do not affect bicycle use altogether, but it leads to some changes. In extreme climatic conditions such as extreme cold, extreme heat, rain and snow, the use of bicycles becomes difficult; the comfort of the journey decreases and due to wet, ice-like reasons, the road surface becomes dangerous and security problem arises (Alpkökin and Elbeyli, 2012). The usage of bicycles considered as a different alternative requires less space compared to other types of transportation, therefore there is more efficient use of roads and parking areas.For example, in a 1 meter band,it can reach a capacity of 1000 people per hour (Table 1).

Table 1. Hourly capacity of separated bicycle strips

Bicycle Strip With Capacity (Bicycle/hour)

\begin{tabular}{|lll|}
\hline $1 \mathrm{~m}$ & 1000 \\
\hline $2 \mathrm{~m}$ & 2000 & \\
\hline $3 \mathrm{~m}$ & 3000 & \\
\hline Source: & Bundesminister & für $\quad$ Verkehr, \\
\hline
\end{tabular}

Forschungsgesellschaft für Stra ßenwesen, 1984

In addition, cycling from the point of view can be considered as a more affordable type of transportation with the lowest cost in the purchase, use and maintenance of sales compared to other types of transportation.

Urban topography is another factor affecting bicycle use.In areas with high slope, people are less willing to choose bicycles. But with the developments in cycling technologies, the use of bicycles with gear, electric and light can be taken against these adversities. Travel distance is another factor that affects bicycle transport. Time and distance are important when making a choice between bicycles and other means of transportation. The average bicycle journey is $15-16 \mathrm{~km} /$ per hour. Intervals when cycling is most intense are usually 20 to 30 minutes or 5 to $8 \mathrm{~km}$ journeys. But, when traveling on longer distances, cycling option is mostly reduced. Therefore, it can be said that the bicycle is a very convenient way of transport for short and medium-distance journeys (Alpkökinand Elbeyli, 2012).

Bicycle which does not need any fuel and engine does not have any negative effect on the environment; it is preferred as environmentally friendly transportation method with pedestrian access as it does not create noise and air pollution. As a result of physical fatigue, the bicycle, which is mostly used for short and medium-distance journeys, it can also serve for the journeys made for different purposes (Öcalır, 2010).

Table 2. Changes in selection of transportation types

\begin{tabular}{|c|l|l|l|l|l|}
\hline Distance & $\begin{array}{c}\text { Bicy } \\
\text { cle } \\
(\%)\end{array}$ & $\begin{array}{c}\text { Public } \\
\text { Transpor } \\
\text { tation(\%) }\end{array}$ & $\begin{array}{c}\text { Pedestria } \\
\mathrm{n}(\%)\end{array}$ & $\begin{array}{c}\text { Automobile( } \\
\%)\end{array}$ & Other(\%) \\
\hline $0-2 \mathrm{~km}$ & 16,8 & 2,4 & 54,5 & 23,5 & 2,8 \\
\hline $2-3 \mathrm{~km}$ & 17,3 & 11,3 & 18,6 & 48,6 & 4,2 \\
\hline $3-4 \mathrm{~km}$ & 12,7 & 16,8 & 9,8 & 5,8 & 4,9 \\
\hline $4-5 \mathrm{~km}$ & 9,0 & $\begin{array}{l}18,1 \\
7,5\end{array}$ & 7,5 & 60,8 & 4,6 \\
\hline $5 \mathrm{~km}$ above & 3,2 & 16,4 & 1,0 & 71,8 & 7.3 \\
\hline
\end{tabular}

Source: Kontıv82, 1984

Bicycle networks are supported that physically identify or separate medium and long-term lanes that can be proposed to improve the bicycle usage. Bicycle networks make a significant contribution to the widespread use of bicycles in the countries and cities where they are used.

In European countries such as the Netherlands, Germany, England and Sweden, bicycle networks are separated from vehicle traffic and the first pass are for bicycles. In contrast to short and broken cycling corridors in US cities, bicycle networks in European cities consist of uninterrupted urban and regional networks that integrate daily action centers (Mert \& Öcalır, 2010).

In addition to physical factors, there are social factors affecting bicycle use.In some societies, including our country, there is a negative perspective towards bicycle transportation, and the bicycle is placed in an underestimated position. It is considered as a mean preferred for children with low income and there is no esteem showed. There is also a negative view of women's cycling. Bicycles are considered as a type of transportation by the 
managers and bicycle arrangements are not taken into account in transportation planning. This negative perspective causes people not to prefer cycling. Apart from all these general factors, personal factors such as bicycle user's age and health status also affect cycling (Alpkökin \& Elbeyli, 2012).

\section{Materials and Methods}

\subsection{Material}

After the 1999 Kosovo war, the population of Pristina had a major migration and population change. The population structure by age and gender is of great importance for the economic and demographic development of the country.

In accordance with the age group of 0-4 age and age group of 95, information is given about the population structure. The graphic shows that the 0-4 age group constitutes the majority of the population compared to other age groups. Population distribution by gender is $50.7 \%$ male and $49.3 \%$ female (MMPH, 2010: 21). Additionally, the information about the population in Pristina is given according to the three age groups (KP, 2013a: 31).

Figure 1. Population of Pristina by age groups

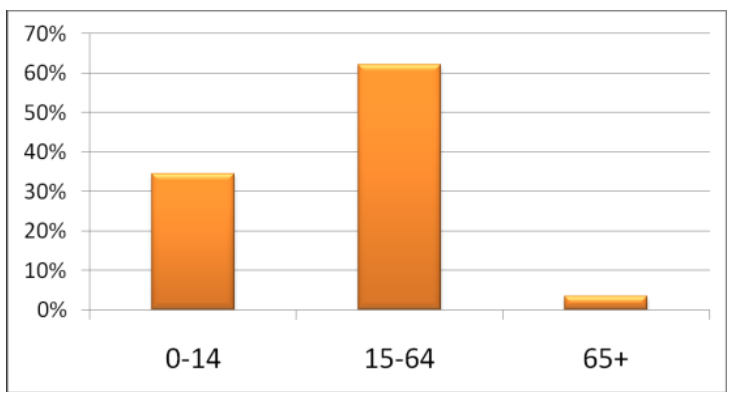

Source: KP, 2013a: 31

The Law of Spatial Planning is not a defined format. The Strategy Plan for urban planning and developing have been drawn up since 2004-2020 and so the city of Pristina has been formed under these charts. The Strategy Plan for Urban Development in Pristina is not the same as the Spatial Planning Law, it has only been the basis for the development of Pristina, and so far, urban planning schemes have been designed on the basis of this study. Regulatory plans in the urban area of Pristina are at the stage of completion. So far 22 regulatory plans have been approved. The city of Pristina is expanding in the south and east (Figure 2).
Figure 2: Regional city plan

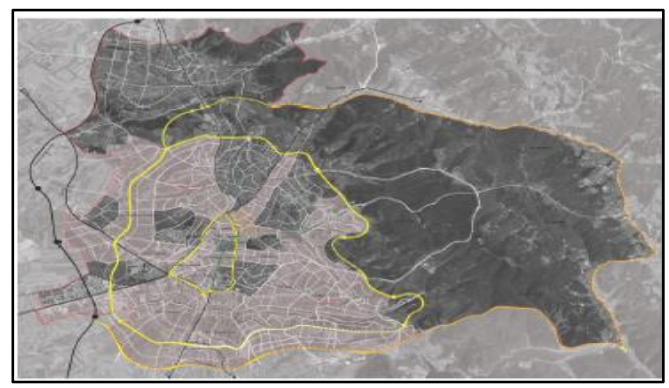

Source: KP, 2013a: 73

In the aftermath of the $2000 \mathrm{~s}$, inter-city transportation was advanced, while irregular and insufficient investments were realized in the urban traffic infrastructure due to the budget and management approach.

The urban roads in Pristina are divided into different categories: Intercity roads:

- It provides inter-citytransportation through the city,

- City roads: It provides transportation between urban and surrounding settlements,

- Urban roads: It provides urban transportation (Figure 3.13.) (KP, 2013a: 96).

According to the 2004-2020 strategic plans, a three-stage road ring is envisaged:

- City center ring road

- Inner ring path covering cityborderline

- Outside ring road covering the borders of the Municipality of Pristina (Figure 3.16.).

"Pristina Urban Development Plan", was realized after the decision of the Municipal Assembly of Pristina and the preparation of the field surveys and development plan was realized with the cooperation of three different companies. In the development plan consisting of a total of five sections and 251 pages, where the urban traffic conditions were also evaluated. In the section of urban spatial development framework, information is given about the investments and corrections to be made by 2022, taking into account the current conditions and infrastructure conditions under the heading of urban traffic system where four stages were identified for the realization of these studies. Within the framework of these stages, it was stated that which investments and corrections should be realized.

First of all, it is stated that traffic should be redirected and it is foreseen that there will be one-way traffic flow especially in a 6 $\mathrm{km}$ city center road ring (Figure 3 ). 
Figure 3. One-way traffic route foreseen in city center ring

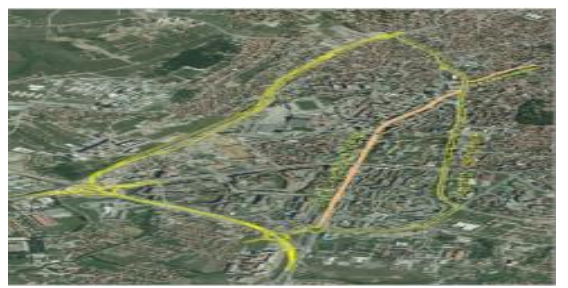

Source: KP, 2013a: 152

With this new arrangement, the former two-way total fourlane road network is envisaged as a lane, in particular as a public transport lane, while the three lanes of the unidirectional flow are anticipated to the general vehicles. On the public transport lane, a tram system was proposed but because of the financial means the use of this lane by buses was pointed out as an alternative option (Figure 3.18.).

Figure 4. Physical road section of the one-way traffic road network foreseen in the city central road ring

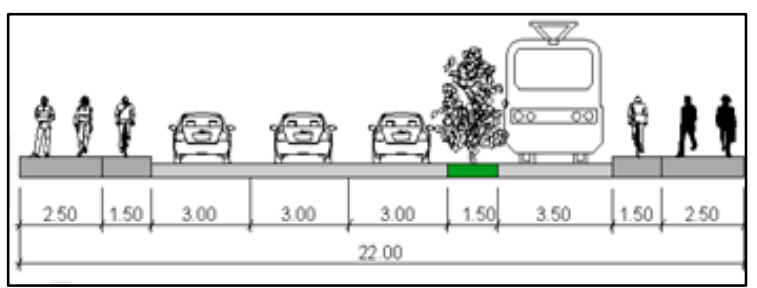

Source: KP, 2013a, 154

There are two different types of traffic management in Kosovo. While municipalities are responsible for urban traffic management and roads, Ministry of Transport and Infrastructure is responsible for theinter-city traffic management and roads. Therefore, urban regulations are designed from the Municipal Assemblies that comply with the central laws. Each municipality is preparing its own regulation, requirements and policies.

\subsection{Methods}

The methodology in the research was developed according to the physical characteristics of the city center in Pristina and the new regulations of the Pristina Development Plan. In this context, in the questionnaires (Figure 4, survey questions and forms of public transport passengers in Pristina), the approach, demand and application possibilities of the passengers against the other transportation systems (except private vehicles) were evaluated. The field research questions were asked to get the thoughts of public transport passengers about these issues. The responses of 782 passengers that are directly or indirectly related with bicycle usage are as follows:
The results of the question "frequency of participation between the age groups":55.6\% of passengers between 19-35 years old, $36.7 \%$ of passengers between $0-18$ years old, $5.8 \%$ of passengers between $36-65$ years old, $1.9 \%$ between $66-100$ years old (Table $3)$.

Table 3. Frequency of participation between the age groups

\begin{tabular}{|l|l|l|l|}
\hline & $\begin{array}{l}\text { Sort by highest } \\
\text { frequency }\end{array}$ & & \\
\hline $\mathrm{Nr}$ & Age & $\begin{array}{l}\text { Frequenc } \\
\mathrm{y}\end{array}$ & $\begin{array}{l}\text { Percentage } \\
(\%)\end{array}$ \\
\hline 1 & $19-35$ & 435 & 55.6 \\
\hline 2 & $0-18$ & 287 & 36.7 \\
\hline 3 & $36-65$ & 45 & 5.8 \\
\hline 4 & $66-100$ & 15 & 1.9 \\
\hline & Total & 782 & 100 \\
\hline
\end{tabular}

In line with these results, 782 public transport passengers are physically suitable for bicycle use, needing frequent transportation in terms of social aspects, and financially considering the use of bicycles more economically; which it constitutes $98 \%$ of the general population of the $0-18,19-35$ and 36-65 age groups and so this suggests that the potential for cycling may be quite high.

The result of the question "evaluation of monthly family income distribution": $\% 56,6$ of the passengers with 0 to $250 €$ income per month, $\% 28,1$ of the passengers with 251 to $500 €$ income per month, $\% 10,1$ of the passengers with 501 to $800 €$ income per month, $\% 5,1$ of the passengers with 801 to $1500 €$ income per month (Table 4).

Table 4. Evaluation of monthly family income distribution

\begin{tabular}{|l|l|l|l|}
\hline \multicolumn{4}{|c|}{ Ranking by highest monthly income holder } \\
\hline Nr. & Family monthly income & Frequency & $\begin{array}{l}\text { Percentage } \\
(\%)\end{array}$ \\
\hline 1 & $0-250$ & 443 & 56.6 \\
\hline 2 & $251-500$ & 220 & 28.1 \\
\hline 3 & $501-800$ & 79 & 10.1 \\
\hline 4 & $801-1.500$ & 40 & 5.1 \\
\hline & Total & 782 & 100 \\
\hline
\end{tabular}

In line with these results, due to the fact that $84.7 \%$ of public transport passengers havea monthly income of 0 to $500 €$, and 
considering that cycling is more affordable than other transportation systems, it is safe to say that the use of bicycle is considered to be more advantageous.

The results of the question "evaluation of preferences for the purpose of transportation": it is seen that $88.6 \%$ of the passengers representing the majority are using the transportation forbusiness and education (Table 5).

Table 5. Evaluation of preferences for the purpose of transportation

Ranking of the highest preferences

according to the purpose of transportation

\begin{tabular}{|l|l|l|l|}
\hline Nr. & Transportation Purpose & Frequency & $\begin{array}{l}\text { Percentage } \\
(\%)\end{array}$ \\
\hline 1 & Education & 353 & 45.1 \\
\hline 2 & Business & 247 & 31.6 \\
\hline 3 & Education / Business & 94 & 12 \\
\hline 4 & None & 49 & 6.3 \\
\hline 5 & Social and Health needs & 19 & 2.4 \\
\hline 6 & Education\&Social and Healthneeds & 7 & 0.9 \\
\hline 7 & $\begin{array}{l}\text { Education \& Business \&Social and } \\
8\end{array}$ & 6 & 0.8 \\
\hline 9 & Social \&Healthneed and None & 3 & 0.5 \\
\hline & Total & 782 & 100 \\
\hline
\end{tabular}

In line with these results, it is shown that students and workers outside the public transport have the potential to prefer cycling.

The result of the question "Why did you choose this type of transportation?": $59.5 \%$ of passengers preferred for the economic reasons (Table 6).

Table 6. "Why did you choose this type of transportation?"

\begin{tabular}{|c|c|c|c|}
\hline \multicolumn{4}{|c|}{ Highest ranking according to transportation purpose } \\
\hline $\begin{array}{l}\mathrm{N} \\
\mathrm{r} .\end{array}$ & Transportation Purpose & $\begin{array}{l}\text { Freque } \\
\text { ncy }\end{array}$ & $\begin{array}{l}\text { Percentage } \\
(\%)\end{array}$ \\
\hline 1 & More Economical & 465 & 59.5 \\
\hline 2 & Fast & 140 & 17.9 \\
\hline 3 & Lack of parking & 46 & 5.9 \\
\hline 4 & $\begin{array}{l}\text { More } \\
\text { Economical\&Fast\&Parking Fees }\end{array}$ & 30 & 2.4 \\
\hline 5 & More Economical \& Fast & 26 & 3.3 \\
\hline 6 & $\begin{array}{l}\text { More Economical\&Lack of } \\
\text { parking }\end{array}$ & 25 & 3.2 \\
\hline 7 & Parking Fees & 19 & 1.8 \\
\hline 8 & More Economical\&Parking Fees & 14 & 0.1 \\
\hline 9 & Lack of parking\&Parking Fees & 13 & 1.7 \\
\hline
\end{tabular}

\begin{tabular}{|l|l|l|l|}
10 & $\begin{array}{l}\text { More Economical \& Fast\&Lack } \\
\text { of parking }\end{array}$ & 2 & 0.3 \\
\hline 11 & Fast\&Parking Fees & 1 & 0.1 \\
\hline 12 & $\begin{array}{l}\text { More } \\
\text { Economical\&Fast\&Parking Fees }\end{array}$ & 1 & 3.8 \\
\hline & Total & 782 & 100 \\
\hline
\end{tabular}

In line with these results, public transport passengers prefer a more affordable way of transportation and the sub-qualification shows that the use of bicycles is an option.

The results of the question "What are your preferences instead of public transport?": $24.3 \%$ of the passengers declare that other than public transport, they do not prefer car or business services (Table 7).

Table 7. "What are your preferences instead of public transport?"

\begin{tabular}{|l|l|l|l|}
\hline \multicolumn{3}{|l|}{$\begin{array}{l}\text { Highest ranking according to } \\
\text { transportation purpose }\end{array}$} & Frequency \\
\hline $\mathrm{Nr}$ & $\begin{array}{l}\text { Transportation } \\
\text { Purpose }\end{array}$ & Percentage (\%) \\
\hline 1 & Automobile & 426 & 54.5 \\
\hline 2 & Business Service & 160 & 20.5 \\
\hline 3 & None & 190 & 24.3 \\
\hline 4 & $\begin{array}{l}\text { Automobile\&Business } \\
\text { Service }\end{array}$ & 6 & \\
\hline 5 & Total & 782 & 100 \\
\hline
\end{tabular}

In line with this result, cycling can be preferred most likely as a different type of transportation other than public transport.

As a result of the implementation of this method, it can be proved that the Pristina Development Plan has the possibility to implement the main route which will form the bicycle network in the framework of the new regulation envisaged in the central ring. In addition, it is possible to apply the cycling lanes in the central ring and in the southwest and southeast settlements of the city, and within these strips, it is possible to apply a two-way bicycle network with a length of $16 \mathrm{~km}$ and a width of $1 \mathrm{~m}$.

\section{Research Findings}

The rate of bicycle usage in Kosovo is much lower than in developed countries. In our country, bicycle is generally considered as a sport activity. The most important reasons for lack of bicycle demand in Kosovo are lack of infrastructure and bicycle culture. The fact that municipalities do not have enough knowledge and experience about cycling are also very important 
reasons. A different reason that affects the bicycle usage is the lack of safe travel conditions in traffic. There are no specific regulations or arrangements related with bicycle usage in the municipality of Pristina.

One of the cities that is suitable for bicycle usage in the Kosovo topography, it is the capital of country, especially in the southwest and southeast of the city of Pristina, where the new settlements have been expanded, and the infrastructure of the central regions arealso very suitable for cycling. At the same time, as a low-cost way of transportation, interest in cycling may increase as the population of Pristina is composed of young people and the unemployment rate is known to be above 50\%. Another element that is different in terms of bicycle usage is the weather conditions. There are four seasons in Kosovo during a year. So, cycling conditions are suitable in 8 months of the year.

One pillar of the TDM strategy is to promote cycling. Bicycle, which is considered as an important mode of transportation all over the world, should be promoted as a means of transportation in Pristina city center as well. For this to happen, a healthy bicycle network should be built.

Pilot routes will be evaluated in different regions, considering the needs of the city's bicycle users and the city's characteristics. Priority was given to the bicycle network in physical arrangements made in public transport arrangements. A bicycle lane has been proposed in both directions of the route, which is approximately $4 \mathrm{~km}$ long, on the central ring route (Figure 5). There is also the possibility for the development of a central ring cycling network, followed by the conditions and feasibility for the construction of bicycle lanes in the southwestern and southeastern regions of the city of Pristina. By evaluating all these opportunities, the citizens will be provided with a different type of transportation, which will be built first in the central ring, inner central ring and in the southwest and southeast regions of the city. The type of bicycle transport is a means that can be used by all young and old, female and male in the city of Pristina. Due to these characteristics, sanctions that encourage the use of it should be brought up by the local authorities.

It should also be considered as a solution for air and noise pollution from Pristina's urban transport. Bicycle services for urban transport should be part of municipal duties in Pristina. As soon as possible, the municipality should initiate a campaign relevant with non-governmental organizations. As the advantages show, bicycle will have an important position in the future world.

In Table 7, the problem-strategy-action plan of the Municipality of Pristina was proposed.

Table 7. Suggestion: The problem - strategy - action plan of the Municipality of Pristina

\begin{tabular}{|c|c|c|c|}
\hline Problem & Strategy & Action & Indicators \\
\hline \multirow{6}{*}{$\begin{array}{l}\text { No importance on } \\
\text { bicycle in transportation }\end{array}$} & \multirow{5}{*}{$\begin{array}{l}\text { Supporting bicycle use as a } \\
\text { type of urban transport }\end{array}$} & \multirow{3}{*}{$\begin{array}{l}\text { It should be given priority to the } \\
\text { bicycle usage plan in the scope } \\
\text { of development plans. }\end{array}$} & Legal arrangements to be made \\
\hline & & & $\begin{array}{l}\text { Development master plan, having an } \\
\text { independent transportation master plan and } \\
\text { have a cycling strip plan included }\end{array}$ \\
\hline & & & $\begin{array}{l}\text { Priority should be given to bicycle routes in } \\
\text { the urban development plan. }\end{array}$ \\
\hline & & \multirow{2}{*}{$\begin{array}{l}\text { City-wide cycling network } \\
\text { creation }\end{array}$} & $\begin{array}{l}\text { Increasing the total length of the urban } \\
\text { bicycle paths (lane-km) }\end{array}$ \\
\hline & & & $\begin{array}{l}\text { Special incentive sanctions for the use and } \\
\text { distribution of various types of bicycles }\end{array}$ \\
\hline & $\begin{array}{l}\text { Establishment of an } \\
\text { infrastructure that will } \\
\text { ensure the safer and } \\
\text { advantageous movement of } \\
\text { bicycles in urban traffic }\end{array}$ & $\begin{array}{l}\text { Supporting the construction of } \\
\text { separate bicycle paths }\end{array}$ & $\begin{array}{l}\text { Increasing the total length of the urban } \\
\text { bicycle paths (lane-km) }\end{array}$ \\
\hline
\end{tabular}

The recommended cycling stripes during physical arrangements of the central ring are strips which can be distinguished only by bicycle users, in a color different from that of the normal road surface (EK- 33). 
The urban cycling network in Pristina will include four distinct regions: the central ring route, the inner central ring, the southwest and the southeast of the city.In these regions, the proposed bicycle lanes are shown on the routes that will be applied by the figures $5,6,7,8,9,10,11,12,13,14,15,16,17$, 18 and 19.

Figure 5. Recommended bicycle lanes within the central ring route

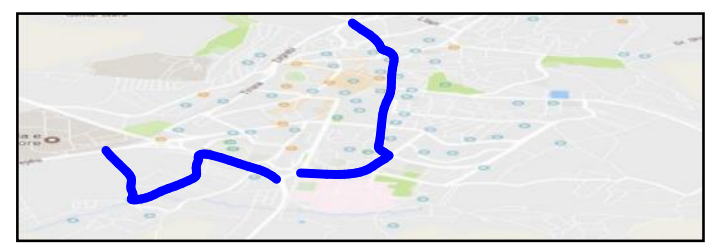

Figure 6. Road section and position of bicycle lanes as a result of rearrangement of the central ring route

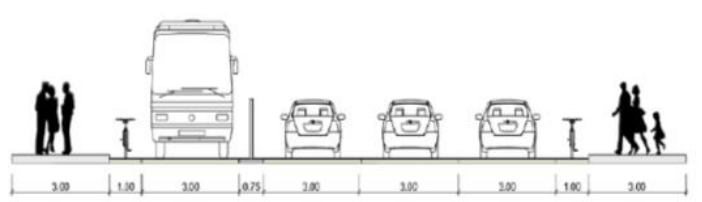

Figure 7. Theinner central ring bicycle network

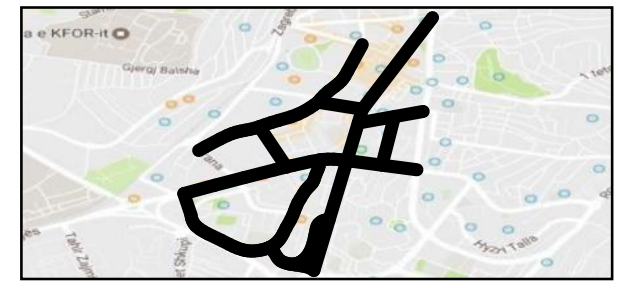

Figure $7.1-7.10$ shows the routes and sections of the roads that form the inner central ring bicycle network.

Figure 7.1. Road: Boulevard Dëshmorët e Kombit (route and cross section)

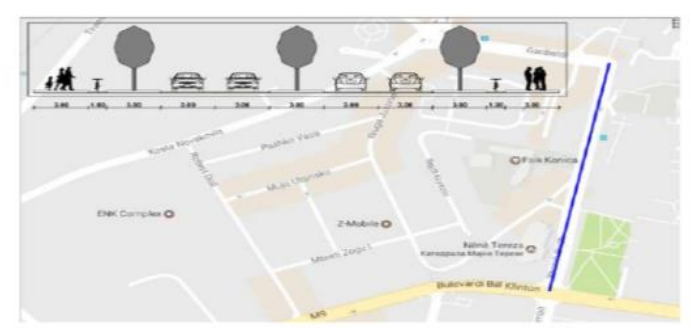

Figure 7.2. Road: Xhorxh Bush (route and road section)

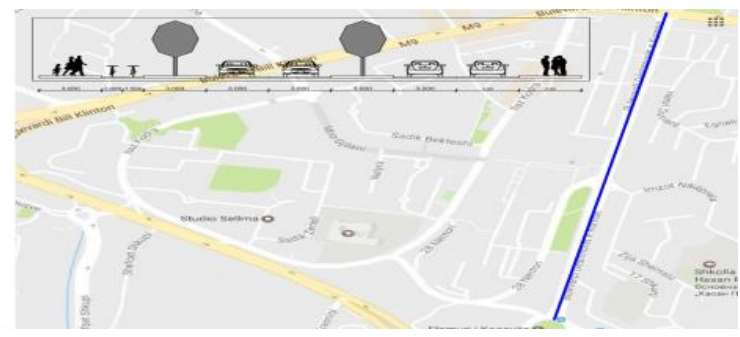

Figure 7.3. Road: Bill Clinton Boulevard (route and road section)

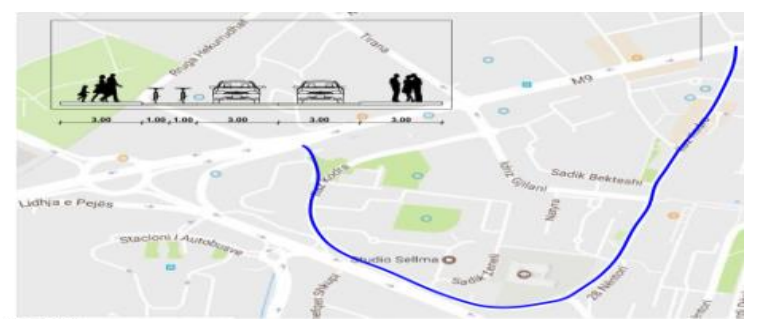

Figure 7.4. Road: lliyaz Kodra (route and road section)

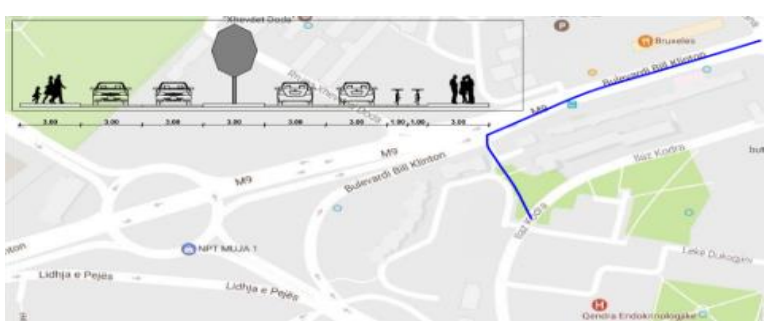

Figure 7.5. Road: 28 Nëntori (route and road section)

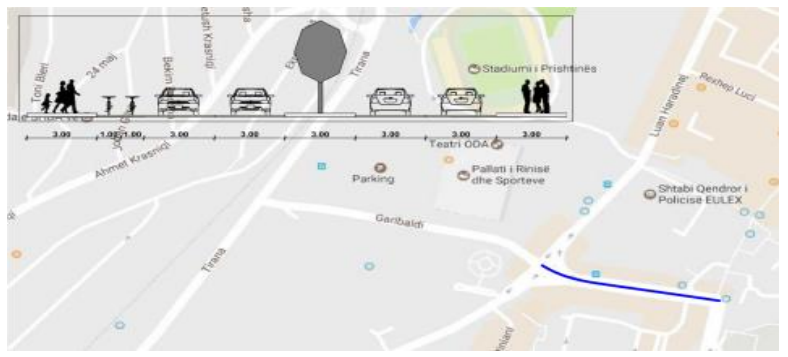

Figure 7.6. Road: Garibaldi (route and road section)

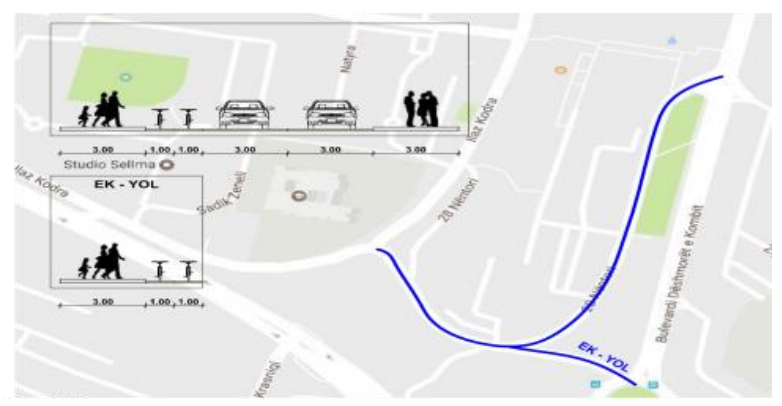


Figure 7.7. Road: Luan Haradinaj (route and road section)

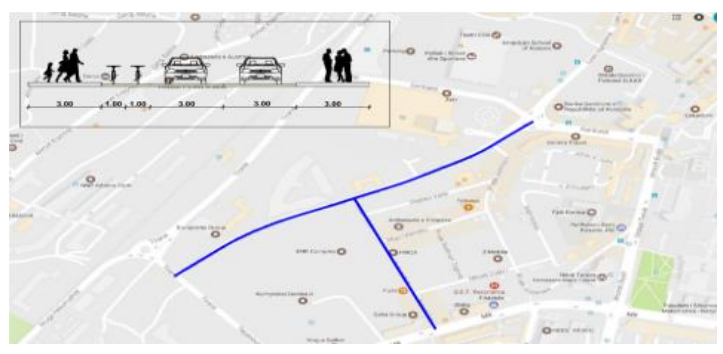

Figure 7.8. Road: Kosta Novakoviç - Robert Doli

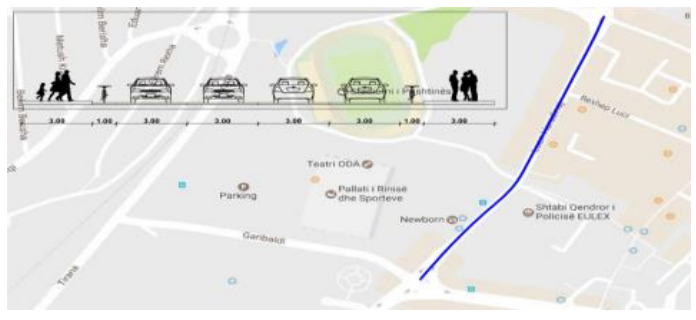

Figure 7.9. Road: Zahir Pajaziti - Nënë Tereza Boulevard (route and road section)

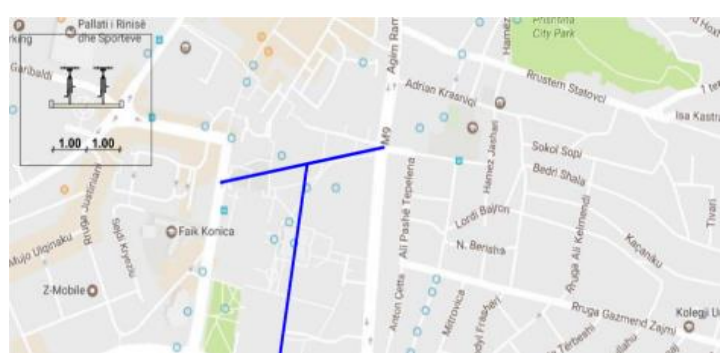

Figure 7.10. Road: Pristina University Campus (route and road section)

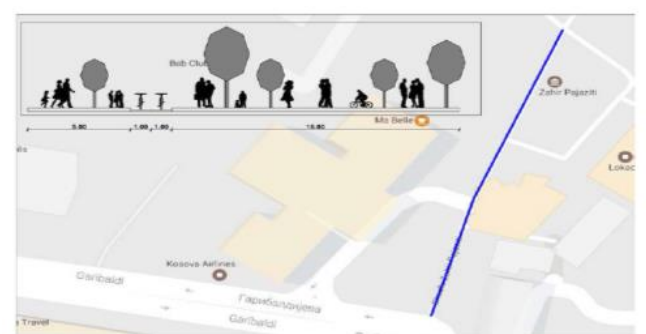

Figure 8. Bicycle route in the central southeastern region of Pristina Road: Shefqet Jakupi - Rexhep Krasniqi

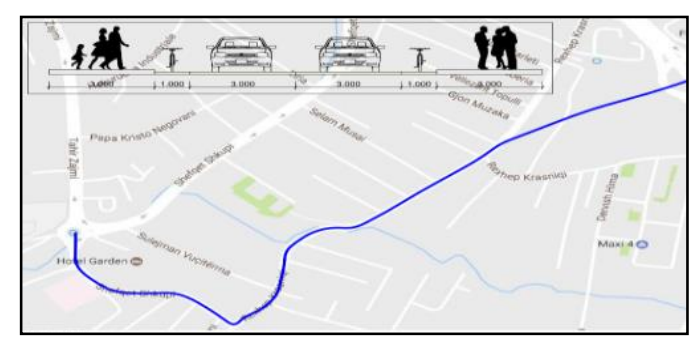

Figure 9. Bicycle route in the central southwestern region of Pristina Road: Muharrem Fejza - Rruga B - Agim Ramadani

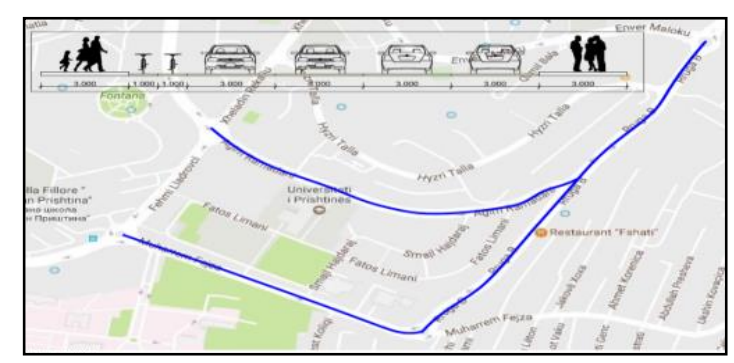

Figure 10. Urban bicycle network in Pristina

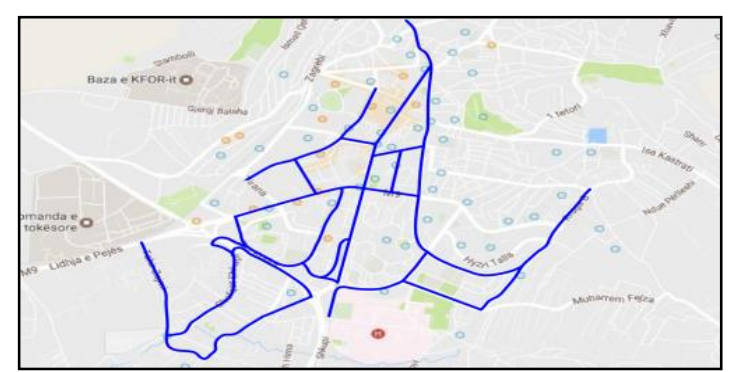

With the generalization of the above mentioned situation, evaluations and suggestions offered for urban bicycle transportation in Pristina, it is possible to reach the latest table on this issue in line with a SWOT analysis.

By means of this analysis, it will be possible to make the bicycle a means of transportation by using the powerful sides of it, to determine the weaknesses and to correct them, to determine the opportunities and to evaluate these opportunities and to identifying the threats and thence the necessary measures should be taken into consideration in order to prevent the potential negative effects of the threats.

Opportunities 
- The proposed cycling network along the center ring is consistent with the route

- High number of young population

- Economically advantegeous

- Existing local government to support bicycle transport

\section{Advantages}

- A large part of the urban topography in Pristina allows the spread of the bicycle network

- Advantage of using bicycles for business, school and sports purposes during the short distance

Threats

- Reaction of private vehicle users

- Current bicycle use and culture

Weaknesses

- Lack of awareness of the public for bicycle as a means of transport

- The lack of infrastructure for bicycle transportation

- No importance given to bicycle policies

- The hill side settlement in the eastern region of Pristina

\begin{tabular}{|l|l|l|}
\hline Status & Evaluation & Comments \\
\hline Traffic reduce & 2 & $\begin{array}{l}\text { It is a cost-effective way to reduce vehicle transport, since conditions } \\
\text { are appropriate in the southwest, southeast and central parts of the city } \\
\text { of Pristina. }\end{array}$ \\
\hline $\begin{array}{l}\text { Reduce of peak clock traffic } \\
\text { alternative methods }\end{array}$ & $\begin{array}{l}\text { The choice of bicycles for passengers living in the southeast and } \\
\text { southwest of the city will contribute to the reduction of urban traffic } \\
\text { density. }\end{array}$ & $\begin{array}{l}\text { The southwestern part of the city of Pristina supports the public } \\
\text { transport by bicycle, with passengers living in the southeast. }\end{array}$ \\
\hline Increase in public transportation & 3 & $\begin{array}{l}\text { The southwestern part of the city of Pristina supports the public } \\
\text { transport by bicycle, with passengers living in the southeast. }\end{array}$ \\
\hline Increase in bicycle use & 3 & $\begin{array}{l}\text { The southwestern part of the city of Pristina supports the public } \\
\text { transport by bicycle, with passengers living in the southeast. }\end{array}$ \\
\hline Increase in bicycle use & 3 & $\begin{array}{l}\text { The southwestern part of the city of Pristina supports the public } \\
\text { transport by bicycle, with passengers living in the southeast. }\end{array}$ \\
\hline
\end{tabular}

\section{Conclusions and Recommendations}

In the last 50 years, in many countries, every municipality carries out some projects on its own scale and on the basis of its possibilities, based on the discussions, but the traffic problems are
In order to increase bicycle use, bicycle parks should be built at many points of the city and especiallyat public transportation stops, so that this type of transportation will be integrated with public transportation.

In countries that have made progress in bicycle transport, there are transport facilities for public transport, thus facilitating integration between bicycle and public transport. The use of bicycles should be encouraged by similar practices to make it attractive, but the vehicles serving in the city of Pristina do not have the opportunity to do so and this issue hasn't been discussed.The location of this type of service will be closed by stops at public transport stops.

With this strategy, the use of bicycles in the city of Pristina may increase, and traffic congestion in the city center will be reduced. If arranged correctly, main street and street traffic flow will also be positively affected. 
through the Pristina example. In the basis of the strategies we mentioned, priority has been given to principles such as using existing infrastructure facilities more efficiently, producing solutions without high cost investments in a sustainable manner and providing a fair transportation service to all segments of the society.

Suggestions are made in accordance with the infrastructure of the route and new regulations are shown with proposed drawings. This arrangement will take place on the $16 \mathrm{~m}$ wide road between the two pedestrian paths (platform). Three lanes for special vehicles with a width of $3 \mathrm{~m}$ and two lanes for bicycles with a width of $1 \mathrm{~m}$ were proposed.

Bicycle lanes, which form the bicycle network in Pristina, will give meaning to bicycle transport integration strategy. Approximately $4 \mathrm{~km}$ of bicycle lanes have been proposed for the new two-way center ring. Approximately 8.5 long bicycle lanes in the central ring of Pristina have been proposed. A two-way cycling route of about $1.5 \mathrm{~km}$ was proposed to complement the Pristina cycling network in the southwestern region of Pristina. In the southeastern region of Pristina, approximately $2 \mathrm{~km}$ two-way bicycle lane was proposed. As a result of these proposals there will be a two-way cycling network in Pristina with a total length of $16 \mathrm{~km}$.

As a result, in accordance with the TDM approach, flexible but easily realized projects from irrevocable high budget investments, light physical corrections from operating investments - operating understanding-legal mechanisms are preferred as solutions for this issue. Within the framework of this understanding, short-term solutions come to the fore.

Urban bicycle network in Pristina: Recommendations should be evaluated in priority order of the following projects:

- Construciton of bicycle lanes,

- Extension of bicycle network,

- Making bicycle paths and necessary markings,

- Priority should be given to bicycle paths in settelement planning,

- Training of drivers and traffic policemen on the rights of cyclists,

- Arrangement of intersections suitable for cycling,

- Construction of bicycle parking areas,

- Slowing down the traffic flow rate

- Investments encouraged by the local government to promote bicycle use,

- Organizing educational campaigns in schools.

\section{References}

1. Alpkökin, P., Elbeyli, Ş. (2012). Kentiçi Ulaşımda Bisikletin Konumu Ve Şehirler İçin Bisiklet Ulaşımı Planlaması: Sakarya Örneği, Yüksek Lisans Tezi, İstanbul Teknik Üniversitesi, Fen Bilimleri Enstitüsü, İstanbul.

2. BUNDESMINISTER FÜR VERKEHR (1980) ForschungsgesellschaftfürStraßenwesen, 1984.

3. CONDON, PM; ISAAC, K. (2003) Green Municipal Engineering For Sustainable Communities, Proceedings of The Institution of Civil EngineersMunicipal Engineer, 156 (1) 3-10.

4. CORSI, M. (2002) The Child Friendly Cities Initiative in Italy, Environment and Urbanization, 14 (2)169-79.

5. Çelik, F. (1999). Geçmişte ülkemizde uygulanan yolculuk talep yönetimi yaklaşımları ve bu yaklaşımların kalıcılığına ilişkin alınması gereken önlemler. II. Ulaşım ve Trafik Kongresi - Sergisi, Ankara.

6. Elker, C. (1999). Çağdaş Ulaşım Politikaları. II. Ulaşım Ve TrafikKongresi - Sergis, Ankara, Yayın no. $242,175-184$.

7. İnternet: KP, (2013a). PlaniZhvillimor Urban Prishtina 2012-2022. Komune e Prishtinës. URL: http://www.webcitation.org/query?url=https $\% 3 \mathrm{~A} \% 2$ F\%2Fkk.rks - ErişimTarihi: 06.07.2017.

8. gov.net\%2Fprishtina\%2Fgetattachment\%2FMunicip ality\%2FDepartments\%2FUrbanizem\%2CNdertimdhe-Mbr-

Mjedisit\%2FUrbanizmi\%2FPZHK\%2FPrishtina_PZ HK_2012-2022_SHQIP.pdf.aspx\&date=2017-08-24 Son ErişimTarihi: 06.07.2017.

9. İnternet: MMPH. (2010). Plani Hapësinor i Kosovës. Strategjia e zhvillimit hapësinor të Kosovës 20102020. Prishtinë: Ministria e Mjedisit dhe Planifikimit Hapësinor.

URL: http://www.webcitation.org/query?url=http\%3A\%2F $\% 2$ Fwww.kryeministri-

10. İyinam, Ş. ve İyinam, A. F. (1999). Kentiçi Ulaşımında Bisiklet Kullanımı. I. Ulusal Kentsel Altyapı Sempozyum Kitabı, Ankara.

11. KAPLAN, H., ULVİ, H. (2005) Ekolojik Kentsel Ulaşımda Bisikletin Yeri, Bu Bağlamda Avrupa Kentlerinden Örneklerin İncelenmesi, Dünya Bisiklet Günü Sempozyumu Bildirileri, Konya; 3-16.

12. Kaya, M. ve ÖCALIR E.V. (2010). Konya'da Bisiklet Ulaşimi: Planlama ve Uygulama Süreçlerinin Karşilaştirilmasi, METU Journal of the Faculty of Architecture, 27(1) 223-240. 
13. Kılınçaslan, T., Elker, C. veSutciffe, E. B. (2012). Kentselulaşım. İstanbul: NinovaYayınları.

14. KONTIV 82 (1984). Kontinuierliche Erhebungzum Verkehrsverhalten, Tabellenband II, Sozialdata, München.

15. RIGHAM, D. (2002) Biking under the Big-Sky - Is human-powered transportation viable in Montana's wide-openspaces (Bike-Net, a bicycle plan for offroad bike trails in Billings), Landscape Architecture, 92 (3) $42-54$

16. Yüksel, H. (1998). Kentiçi ulaşımda talep yönetimi. Yüksek Lisans Tezi, Yıldız Teknik Üniversitesi, Fen Bilimleri Enstitüsü, İstanbul. 